\title{
血管の不均一部が脈波に及ぼす影響*
}

\author{
渡辺知規 ${ }^{* 1}$

\section{Effect of an Inhomogeneous Part in Blood Vessel on Pulse Wave}

\author{
Tomonori WATANABE*2 \\ *2 Graduate School of Engineering, Chiba University, \\ 1-33 Yayoi-cho, Inage-ku, Chiba-shi, Chiba, 263-8522 Japan
}

\begin{abstract}
The effect of an inhomogeneous part in a blood vessel on pulse wave has been investigated by using a one-dimensional lattice model associated with the material nonlinearity of the arterial vessel wall. In the present study, from the viewpoint of mechanics, a certain part of blood vessel, which has the different configuration and mechanical properties of the arterial vessel wall, is regarded as the inhomogeneous part by a generalization. The stability of the solitary wave is applied in order to obtain the reliable results by the numerical analysis of the pulse wave which propagates through the inhomogeneous part in the blood vessel. As a result, the behaviors of the pulse wave which propagates through the inhomogeneous part are shown. The factor which has the effects on the propagation of the pulse wave is revealed. Moreover, the relations between the behaviors of the pulse wave and the properties of the inhomogeneous part are clarified.
\end{abstract}

Key Words: Computational Fluid Dynamics, Bio-Fluid Mechanics, Nonlinear Dynamics, Soliton, Exact Solution

\section{1. 緒言}

動脈硬化症は，脳梗塞や心筋梗塞などの原因ともな り，血管系の疾患に扔いて，近年，大変深刻な問題と なっている(1). 一般に, 動脈硬化は血管壁の一部にお いて，形態，および，力学的性質に異变が生じること に起因するとされている，それゆえ血管系の解析にお いて，血管壁の形態や力学的性質が異なる部位が血管 を伝播する圧力脈波に及ぼす影響を明らかにするこ とは，物理学や医学の観点からだけでなく医療などへ の工学的応用といった観点からも重要であると考えら れる。

現在，血管系の解析においては，血管を伝播する圧 力脈波について一次元モデルを用いた研究 ${ }^{(1) \sim(8)}$ が活発 になされている．とりわけ血管の一次元格子モデルを 用いたこれまでの研究 ${ }^{(6)(7)} に$ においては血管壁に力学的 性質の異なる部位が存在する場合を対象とし，血管壁 の力学的性質が異なる部位を血管の異質部として一般 化して捉えることにより，異質部の存在によってもた らされる脈波への影響が明らかにされている.ただし， これらの研究においては異質部での力学的性質は一様

* 原稿受付 2008 年. 10 月 20 日.

*1 正員, 千葉大学大学院工学研究科人工システム科学尃攻 (焉263-8522 千葉市稻毛区弥生町 1-33).

E-mail : nabe@meneth.tm.chiba-u.ac.jp
として取り扱われているのに対し，一般に，動脈硬化 部では力学的性質だけでなく，狭窄など，血管形態の 変化も含めてそれらは一様ではなく不均一に分布して いることが知られている.ゆえに動脈硬化部の存在が 脈波の伝播に及ぼす影響を明らかにするためには，単 純に血管壁の形態や力学的性質が正常部と異なってい るということだけでなく，それらが不均一に分布して いるということも考慮して取り扱うことが重要である.

そこで，本研究では，血管壁の形態や力学的性質が, 正常部と比べて不均一に分布している部位を，力学的 観点から血管の不均一部として一般化して捉えること により，動脈硬化部や動脈瘤部など，血管に生じた不 均一部が脈波に及ぼす影響を力学的観点から広く明ら かにすることを目的とする.

本研究の特徵は, 主に以下の三つにある. まず第一 に，一般に，動脈硬化や動脈瘤など血管の形態や力学 的性質の異変と深い関わりをもつとされる血管系疾患 に対する基礎的知見を得るために，脈波の振舞いに影 響を及ぼす様々な因子の中で，血管壁の形態や力学的 性質に焦点を絞っている点である，つぎに第二には， 血管壁の形態や力学的性質の異変を力学的観点から血 管壁の不均一性として一般化して捉えている点である. これにより病変部が脈波に及ぼす影響を力学的観点か ら統一的に理解するだけでなく，脈波伝播速度 ${ }^{(9)(10)}$ 
などの力学的デー夕に基づく診断法の確立に有益な知 見を得ようとするねらいがある，最後に第三には，伝 播する脈波に変化が生じた場合に不均一部の存在に起 因する影響を的確に把握するために，脈波のモデルと して衝突や擾乱などに対して安定な孤立波であるソリ トン(5) (8) (11) (12)を応用している点である.

以上のことをふまえ，まず第 2 章では，血管壁性状 の変化を力学的観点から不均一部として一般化して取 り扱う方法について明らかにする.さらに本研究にて 対象とする不均一部を有する血管の一次元格子モデル を導入し，モデルの方程式を導出する．つぎに第 3 章 では，第 2 章にて導入した一次元格子モデルについて， 血管壁の性状を具体的に与え, 数值解析を行う方法に ついて述べる. 最後に第 4 章では, 数值計算結果をも とに脈波が不均一部を通過する際に生じる変化と血管 壁性状との関係について考察を行い，血管の不均一部 が脈波に及ぼす影響を明らかにする.

\section{2. 不均一部を有する血管の一次元格子モデル}

本章では，まず，血管壁の形態や力学的性質などの 性状の変化を力学的観点から不均一部として一般化し て取り扱う方法について明らかにする，つぎに，本研 究にて対象とする不均一部を有する血管の一次元格子 モデルを導入し，モデルの方程式を導出する.

本研究では, 前章でも述べた通り, 動脈硬化や動脈 瘤など血管の形態や力学的性質の異変と深い関わりを もつとされる血管系疾患に対する基礎的知見を得るた めに, 脈波の振舞いに影響を及ぼす様々な因子の中で, 血管壁の形態と力学的性質に焦点を絞って考察を行う という极らいがある。そこで不均一部を有する血管の モデルを導入するにあたっては, これまでの研究(5) (7) をもとに，血管壁の材料非線形性の影響を考慮した血 管の一次元格子モデルである坂西モデル ${ }^{(8)}$ を基礎にお くものとする.ここで坂西モデルとは，血管壁の材料 非線形性の影響を考慮するために種々の実験データの 検討から血管壁の応力 $\sigma$ とひずみ $\gamma$ の関係を表す構 成則として,

$$
\sigma=\sigma_{0}\left\{\exp \left(\frac{\gamma}{\gamma_{0}}\right)-1\right\},
$$

を採用することによって，血管の最低血圧に対する圧 力差 $p$ の時間的挙動を非線形方程式 :

$2 \rho l^{2} \gamma_{0} \frac{\mathrm{d}^{2}}{\mathrm{~d} \tau^{2}} \log \left(1+\frac{p_{n}(\tau)}{p_{0}}\right)$

$$
=p_{n+1}(\tau)-2 p_{n}(\tau)+p_{n-1}(\tau),
$$

によって記述するモデルである ${ }^{(8)}$. ただしここで，時 間を $\tau$ とし, 軸方向の位置 $x$ については, 離散間隔 $l$ にて空間離散化を行い，任意の整数 $n$ を用いて $x=n l$
とした. また $\rho$ は血液の密度であり, $p_{0}, \gamma_{0}$, および, $\sigma_{0}$ は血管壁の材料特性を表す定数とし, 血管の内側 半径を $R$, 血管壁の厚さを $h$ とした時に, $p$ と $\sigma$ の間 に成り立つ関係として，

$$
0=p-\frac{h}{R} \sigma,
$$

を用いた ${ }^{(8)}$. 坂西モデルは構成則 (1)のもつ材料非線 形性に焦点を絞った非常にシンプルなモデルではある が, このモデルからは種々の興味梁い結果が得られて おり, 今もな括活発に研究がなされている ${ }^{(5) \sim(8)}$.

本研究では, 非常にシンプルなモデルである坂西モ デルを不均一部を有する血管のモデルとして拡張し， モデルを可能な限りシンプルにすることにより，血管 壁性状と脈波の挙動との関係を浮き彫りにすることを 試みる.このために本研究のモデルでは, 動脈硬化部 や動脈瘤部など血管壁において形態や力学的性質の異 なる部位を，個別の状況の詳細にこだわるのではなく 力学的観点から一般化をして取り扱うものとする. 具 体的には, 坂西モデルにおいて，方程式 (2) の導出の 際に定数として取り扱っていた血管壁の形態や力学的 性質を表す四つの力学的なパラメータ $\left(R, h, \sigma_{0}\right.$, お よび， $\gamma_{0}$ ）を血管の部位（軸方向の位置）に依存する 変数として取り扱うものとする.すなわち，血管にお ける病変部のモデル化として, 血管壁性状を表す上述 の四つの力学的なパラメータについて, 病変部では正 常部とは異なる值を与えることによって血管壁性状の 不均一性を表すものとする. 本研究では, このように 血管壁性状が不均一になる部位を, 不均一部, と呼び, 不均一部を有する坂西モデルを不均一部を有する血管 の一次元格子モデルとして取り扱う. 以下では実際に モデルの方程式を導出する.

まず，上述の四つの力学的なパラメータについて， 便宜上, 関係式 (3) を用いて $p$ も加え, 正常部では定 数値として, $R^{(0)}, h^{(0)}, \sigma_{0}^{(0)}, \gamma_{0}^{(0)}$, および, $p_{0}^{(0)}$ とし, 不均一部ではこ扎らの值が血管の軸方向の位置 $x$ に 依存して分布しているものとし, $R(x), h(x), \sigma_{0}(x)$, $\gamma_{0}(x)$, および, $p_{0}(x)$ とおくものとする. つぎに, こ れらのパラメータを用いて, 構成則 (1) から, 血管壁 の応力 $\sigma$ とひずみ $\gamma$ の関係式を,

$$
\sigma(x, \tau)=\sigma_{0}(x)\left\{\exp \left(\frac{\gamma(x, \tau)}{\gamma_{0}(x)}\right)-1\right\},
$$

とする. さらに, この関係式に式 (3) を用いて, $p$ と $\gamma$ の関係式として,

$$
p(x, \tau)=\frac{h(x)}{R(x)} \sigma_{0}(x)\left\{\exp \left(\frac{\gamma(x, \tau)}{\gamma_{0}(x)}\right)-1\right\},
$$

とする.この関係式では, 不均一部における形態的要 因 $(R や h)$ と力学的性質による要因 $\left(\sigma_{0}\right)$ をまとめ 
て取り扱うことができるので, 結局, 関係式 (5) は, 本 質的には二つのパラメータを用いてまとめることがで き, 実際に位置 $x$ に依存する二つの無次元パラメータ を， $a(x)$, および, $b(x)$ を用いて,

$$
p(x, \tau)=p_{0}^{(0)} a(x)\left\{\exp \left(\frac{b(x)}{\gamma_{0}^{(0)}} \gamma(x, \tau)\right)-1\right\},
$$

と表すことができる.ただし，

$$
a(x):=\frac{p_{0}(x)}{p_{0}^{(0)}}=\frac{h(x) / h^{(0)}}{R(x) / R^{(0)}} \frac{\sigma_{0}(x)}{\sigma_{0}^{(0)}}, \quad b(x):=\frac{\gamma_{0}^{(0)}}{\gamma_{0}(x)},
$$

とした。したがって，関係式 (6) を用い，坂西モデル の場合之同様に圧力差 $p$ についての時間的挙動を求 め, 空間離散化 : $x=n l$ と規格化のための変数変換 :

$$
f_{n}(t):=\frac{p_{n}^{(1)}(\tau)}{p_{0}^{(0)}}, \quad t:=\left(\frac{p_{0}^{(0)}}{2 \rho l^{2} \gamma_{0}^{(0)}}\right)^{1 / 2} \tau,
$$

を行うと，血管の不均一部を考慮した一次元格子の方 程式として,

$$
\frac{\mathrm{d}^{2}}{\mathrm{~d} t^{2}} \log \left\{1+\frac{f_{n}(t)}{a_{n}}\right\}=b_{n}\left\{f_{n+1}(t)-2 f_{n}(t)+f_{n-1}(t)\right\},
$$

を得ることができる. 本研究では，この式を不均一部 を有する血管の一次元格子モデルの方程式として用い るものとする.

ここで方程式 (9) の導出にあたって注意すべきは, 本 研究のモデルでは, 血管壁の形態や力学的性質などの 血管壁性状の変化は任意に与えることができるので, 血管壁の病変に限らず血管のもつテーパーなど血管壁 性状の変化に対し広く一般的に考察の対象とすること ができるということである.このことは本研究の大き な特徵のひとつとなっている. また，あえて血管壁の 形態や力学的性質に関わる各パラメータを位置 $x$ に依 存しない定数にした場合を考えてみると, 式 (7) から, 方程式 (9) における二つのパラメータ $a$ と $b$ は定数亡 なり,これらのパラメータ值が正常部と不均一部とで 等しい時には, 方程式 (9) は坂西モデルの方程式 (2) と等しくなり, 正常部と不均一部とで異なる時には既 報(6)(7)にて取り扱った異質部を有する血管モデルの方 程式と等しくなる.このことから本研究のモデルが, 坂西モデルや異質部を有する血管モデルを内包し一般 化したモデルになっているということも確認すること ができる.

ではここで，方程式 (9)に含まれる血管の不均一性 を表す二つの本質的な無次元パラメータ $a$ と $b$ はどの ような物理的意味をもつのであろうか? 各パラメー 夕 $a$ と $b$ について, 離散化を行う前の定義式 (7)の 導入の際においても述べた通り， $a$ は不均一部におけ
る形態的因子 $(R$ と $h)$ と力学的性質による因子 $\left(\sigma_{0}\right)$ に関わる影響を取りまとめた量であり，正常部に対す る不均一部の圧力差の割合を表す。一方, $b$ 注不均一 部における力学的性質による因子のなかでも特に構成 則の初期ひずみ $\gamma_{0}$ に関わる影響を取り扱った量であ り，構成則においては非線形性の度合を表し， $b$ が大 きくなるほど血管壁の材料非線形性が大きくなるとい うことがわかる. またパラメータの積 $a b$ は,

$$
a(x) b(x)=\frac{h(x) / h^{(0)}}{R(x) / R^{(0)}} \frac{\sigma_{0}(x) / \gamma_{0}(x)}{\sigma_{0}^{(0)} / \gamma_{0}^{(0)}},
$$

となり，血管壁の形態に変化がない場合，すなわち， $h(x)=h^{(0)}$, および, $R(x)=R^{(0)}$ の場合では, $a(x) b(x)$ は応力-ひずみ曲線のひずみが零での傾きについて, 正 常部に対する不均一部の割合を表しているということ がわかる.したがって，このことから $a(x) b(x)$ は応力 ひずみ曲線のひずみが零での傾き（ヤング率）という 物理的意味も含んだ血管壁の性状を表す物理量である と理解できる. 以下では，不均一部を通過する脈波の 振舞いを明らかにするために，方程式 (9) について， 具体的に $a_{n}$ と $b_{n}$ を与え数值解析を行う.

\section{3. 解 析 方 法}

本章では, 前章にて導出した方程式 (9)について, 実際に数值解析を行う方法について明らかにする。ま ず，血管壁の性状を具体的に与える.すなわち，以下 では，数値解析を行うにあたり，血管壁の不均一性の 一例として, 不均一部を, 分散を $s^{2}$ とする正規分布を 参考にしてモデル化し，方程式 (9)の二つのパラメー 夕 $a_{n}$ と $b_{n}$ の各分布を二つの定数 $A$ と $B$ を用いて,

$$
\begin{aligned}
& a_{n}=1+A \exp \left\{-\frac{(n-L / 2)^{2}}{2 s^{2}}\right\}, \\
& b_{n}=1+B \exp \left\{-\frac{(n-L / 2)^{2}}{2 s^{2}}\right\},
\end{aligned}
$$

として与えるものとする，ただし，不均一部の長さを $L=10 s$ とし, 数値計算の際には, 便宜上, $n=L / 2 \pm 5 s$ となる位置において $a_{n}$ と $b_{n}$ の各分布にカットオフ を入れるものとする．以上のことから，不均一部は $0 \leq n \leq L$ において存在し， $a_{n}$ と $b_{n}$ は不均一部の中心 の位置 $n=L / 2$ において最大值もしくは最小值をとり, $n= \pm \infty$ において 1 となる釣鐘型の分布をしているこ とがわかる.また，分布の幅はしが大きくなるほど大 きくなり, 分布の頂点の高さの絶対值は, それぞれ $A$ とBの絶対値が大きくなるに従って大きくなるという ことがわかる.なお，これまでの研究においても，例 えば，狭窄を有する血管のモデル化のために，本研究 と同様に正規分布を応用するということは行われてお 
$り^{(10)}$ ，不均一部の例として式 (11) と (12)を与えると いうことは，基礎的知見を得るという段階においては 妥当であると考えられる.

つぎに，数值解析における初期条件としては，第 1 章においても述べた通り, 脈波のモデルとしてソリト ンを応用する．ここでソリトンとは衝突や擾乱などに 対して安定な性質をもつ孤立波のことであり，これま での多くの研究においても脈波に対しソリトンを用い た議論がなされている(5) (8)(11)(12). 本研究においては 特にソリトンのもつ安定性に着目をする。

一般に，波は分散性などにより時間とともに波形を 変化させることがある.この場合, 本研究においては, 不均一部の存在の有無にかかわらず波形が変化するこ とになるため，不均一部によってもたらされる脈波へ の影響を特定することが困難になるものと考えられる. そこで, 通常では, 波形に顕著な変化が生じないとい うソリトンのもつ安定性を活用すると, 不均一部を有 する血管において波形に変化が生じた場合には，変化 をもたらした要因が不均一部の存在にあるものとして 特定することができ，ゆえに脈波が不均一部を通過す る際の振舞いについて的確に把握できるものと考えら れる. よって, 本研究での解析においては初期条件と してソリトンを用いるものとする。

実際に，前章に拈いて導出した方程式 (9) は非線形 方程式であり，一般に解析が非常に困難な方程式であ るにもかかわらず $a_{n}=1$ および $b_{n}=1$ とした場合には,

$$
f_{n}(t)=\sinh ^{2} k \operatorname{sech}^{2}(k n-\omega t),
$$

という厳密解をもつ ${ }^{(5) \sim(8)(11)}$. ただしここで $k$ は波数 であり，周波数 $\omega$ は分散関係式： $\omega= \pm \sinh k$ によって 定まるものとする. また, 解 (13) は1ソリトン解と呼 ばれ $1 / k$ の幅をもつ安定な孤立波であることが知られ ている(11). 以上のことから，本研究では，この解を脈 波のモデルとして採用し，不均一部を通過する脈波の 振舞いについて検討を行うものとする. ただし波数 $k$ は $k=0.1$ とする.

最後に，数值解法亡しては，これまでの研究(6)(7)で は，坂西モデルを対象とした数值解析上の信頼性に ついての検討結果 ${ }^{(5)}$ を踏まえ，シンプレクティックス キーム ${ }^{(13)}$ を採用している。そこで，これまでの研究結 果 ${ }^{(5) \sim(7)}$ との比較も考慮し, 本研究においても 4 次のシ ンプレクティックスキームを用いるものとする．ただ し時問についての差分間隔 $\Delta t$ は $\Delta t=0.1$ とする.

\section{4. 結果と考察}

$4 \cdot 1$ 不均一部を通過する脈波の振舞い睬 1 に, 不均一部を通過する脈波の振舞いについて代表的な例
として, 不均一部長さ $L$ を $L=100$ とし, 前章での式 (11) と (12) にて与えたパラメータ $a_{n}$ と $b_{n}$ 中の $A$ と $B$ を，それぞれ $A=0.7$ および $B=0.6$ とした場合で の圧力脈波の時間発展の様子を示す。このような状況 は，式 (7)によると，例えば，血管壁性状を表す四つ のパラメータのうち $\sigma_{0}(x)$ と $\gamma_{0}(x)$ のみ変化する場合 を考えると，血管の不均一性として，血管壁の応力-ひ ずみ曲線において，ひずみが零での傾き（ヤング率） と非線形性が不均一部中央に向かって次第に大きくな り，中央部にて最大值をとるように，血管壁の力学的 特性が変化している場合を表している，また，式 (11) と (12) にて与えたパラメータによる不均一部での分 布の対称性を考慮して, 図 1 と同じ $A$ と $B$ のもとで, 不均一部が存在する範囲を $0 \leq n \leq L / 2$ とした場合と， 不均一部が存在する範囲を $L / 2 \leq n \leq L$ とした場合に 分けて数值計算を行った結果を，それぞれ図 2 と図 3 に示す．なお，いずれの図においても参考として，圧 力脈波の大きさを $n-t$ 平面に正射影したコンター図 も示した.ただし図中の各線の間隔は 0.2 とした。

まず，図 1 によると，不均一部から充分に離れた位 置から血管の正常部を伝播してきた脈波は，波形を変 えずに時刻 $t=0$ において不均一部左端 $(n=0)$ に到達 する，すると，しだいに脈波は，不均一部中点 $(n=50)$ に達するまでに振幅と速度を変化させながら伝播をし， さらに反射波を発生させる。図 1 の場合では，脈波の 振幅と速度は増加し，正の振幅をもつ反射波が発生す る。つぎに，不均一部中点を通過した脈波は，不均一 部右端（ $n=100 ） に$ 到達するまでに，さらに振幅と速 度を変化させ，再び反射波を発生させる．図10場合 では，先程とは逆に脈波の振幅と速度は減少し，負の 振幅をもつ反射波が発生する. その後, 不均一部を通 過した脈波は血管正常部中を伝播していく.

以上のことから，血管壁の形態と力学的性質の不均 一性は，脈波の振幅と速度，および，反射波の振幅に 変化をもたらし，それらの変化は，脈波が存在してい る位置における血管壁の形態と力学的性質に依存する ということがわかる。事実，図 1 の場合では， $a_{n}$ と $b_{n}$ はともに上に凸な分布であり， $a_{n}$ と $b_{n}$ の増減に伴 い，脈波の振幅之速度，および，反射波の振幅の符号 も変化している.さらに不均一部透過後には，脈波の 振舞いは不均一部入射前の状態を回復していることが わかる．また，特に反射波については，血管の異質部 を取り扱ったこれまでの研究(6)(7)では，脈波が異質部 に入射する際と異質部から正常部に透過する際にそれ ぞれ独立して反射波が観測されていたのに対し，本研 究の場合では，脈波が不均一部を通過する際には互い 


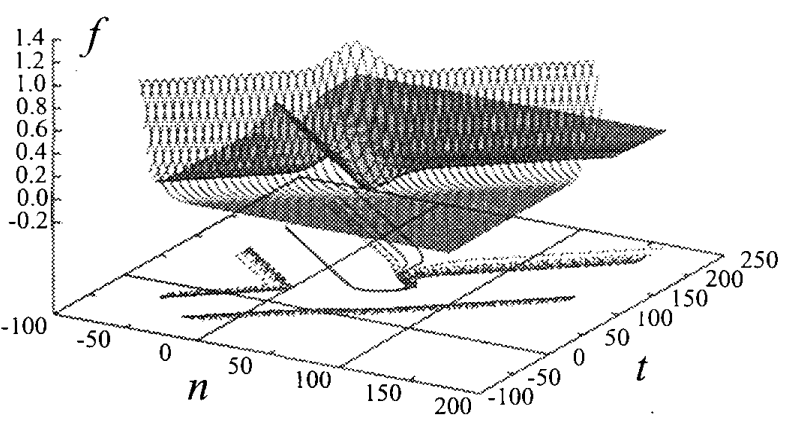

Fig. 1 Propagation of the pressure wave through the inhomogeneous part for $L=100, A=0.7$ and $B=0.6$.

に振幅の符号が異なる二つの反射波が連なつて現れて いる. 図 2 と図 3 によると, 式 (11) と (12) における 分布の対称性に起因して脈波の振幅と速度の増減は, 図 2 と図 3 とではそれぞれ逆の傾向を示し，反射波 についても符号の異なる反射波が発生している。しか し，このような反射波が，図1のように連続的に増減 する不均一部において発生した場合には異質部の場合 とは違い，不均一性が増加する際に発生する反射波之 不均一性が減少する際に発生する反射波との間隔が各 反射波の幅に比べて小さくなり，その結果として，図 1 にあるような波の連なりとして現れたものと考えら れる．これは，異質部を扱った既報(6)(7) と比べて血管 壁性状の変化の增隇を連続的に捉えた本研究の特徵と なっている. 以下では, 便宜上, パラメータ $a_{n}$ と $b_{n}$ がもつ対称性を考慮して，不均一部左端（ $n=0 ）$ から 不均一部中点 $(n=L / 2)$ までに着目する.

$4 \cdot 2$ 脈波に変化をもたらす要因前節では, 血 管壁性状の变化，すなわち，血管壁の形態や力学的性 質の不均一性によって，不均一部を通過する脈波の振 舞いに変化が生じることが明らかになった。では，不 均一部を通過する脈波に変化をもたらす具体的な要因 は何なのであろうか?

前節での結果をふまえ，不均一部を $L=100$ のもと で, 不均一部左端 $(n=0)$ 加ら不均一部中点 $(n=L / 2)$ までとして, $A$ と $B$ を変化させた場合の位置 $n=-50$ における反射波の振幅の最大值 $f_{\mathrm{R}}$ を図 4 に, 不均一 部中点 $n=50$ に拈ける脈波の振幅の最大值 $f$ を図 5 に, また, 不均一部中点 $n=50$ における脈波の速度 $v$ を図 6 に示す．ただし各図中の $a$ と $b$ の值は比較の便 宜上，不均一部中点における值を意味するものとした。

図4から図6によると，大きな特徵として，いずれ の図においても，おおむね $a=b$ がなす面に対称とな る傾向があることがわかる．これは，不均一部を通過 する脈波の振舞いが $a b$ の大きさによって特徽づけら

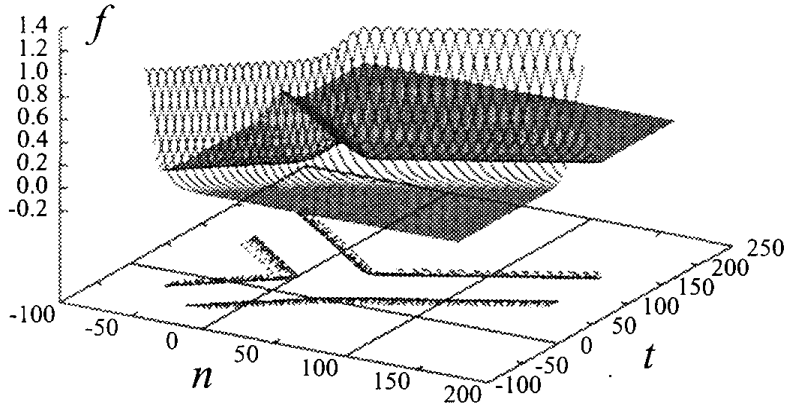

Fig. 2 Propagation of the pressure wave through the inhomogeneous part: $0 \leq n \leq L / 2$ for $L=100$, $A=0.7$ and $B=0.6$.

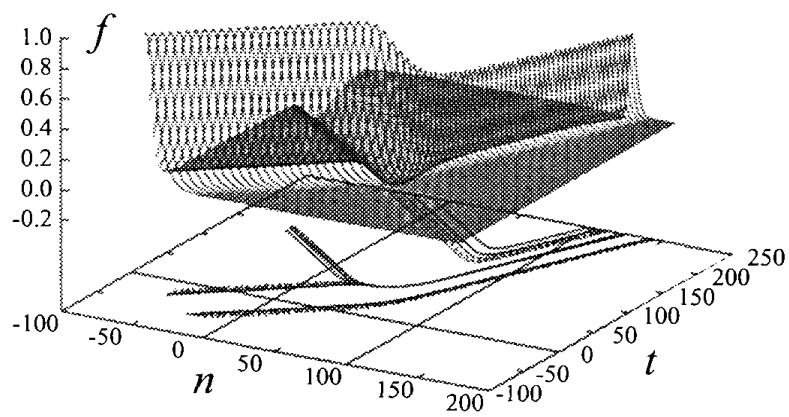

Fig. 3 Propagation of the pressure wave through the inhomogeneous part: $L / 2 \leq n \leq L$ for $L=100$, $A=0.7$ and $B=0.6$.

れることを意味する.

実際に，まず，図 4 においては， $a b$ の值が一定で あれば最大振幅 $f_{\mathrm{R}}$ の值もほぼ一定となり， $a b$ の值が 大きくなるにつれ反射波の振幅の值が大きくなってい る. 特に, $a b$ の大きさと反射波の振幅の符号との関 係に着目すると, $a b<1$ の場合, 振幅は負となり, 逆 に, $a b>1$ の場合では振幅は正となる. さらに, $a b=1$ では，反射波の振幅は，ほぼ零，すなわち，反射波が 発生しないことがわかる.つぎに，図 5 においては, $a b<1$ の場合, 振幅は 1 より小さくなり, 逆に, $a b>1$ の場合では，振幅は 1 より大きくなる. また, $a b=1$ では，振幅は，ほぼ1となっている. 事実, 最大振幅 $f$ と $a b$ との関係を数值計算結果から見積もると,

$$
f=(a b)^{0.3},
$$

となり, 最大振幅 $f$ はパラメータの積 $a b$ に依存する ことがわかる，最後に，図 6 の速度の場合も図 5 の場 合上同様に, $a b<1$ の場合, 速度は 1 より小さくなり, 逆に, $a b>1$ の場合では, 速度は 1 より大きくなる. また， $a b=1$ では，速度は，ほぼ 1 となることがわか る. 実際に, 速度 $v$ と $a b$ との関係を数值計算結果か ら見積もると，

$$
v=(a b)^{0.5},
$$




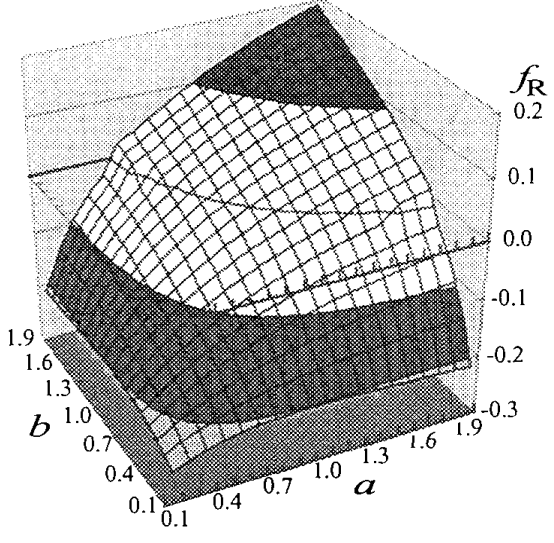

Fig. 4 Maximum amplitude of the reflected wave at $n=-50$, which splits from the pressure wave through the inhomogeneous part: $0 \leq n \leq L / 2$.

となり, 速度 $v$ も, 最大振幅 $f$ と同樣に, パラメータ の積 $a b$ に依存することがわかる.

以上のことから，脈波に変化をもたらす要因は，二 つのパラメータの積 $a b$ であるということがわかる. また，これまでに血管壁の力学的性質が急激に変化す る異質部を取り扱った研究結果によると，パラメー夕 の積 $a b$ は, 脈波の振舞いを, とりわけ非線形性が弱 い場合において顕著に特徵づける物理量であることが 知られている(6)(7). したがって, このことと, 本研究 での結果をふまえると, 本研究のように血管壁の力学 的性質だけでなく血管壁の形態もゆるやかに変化する 不均一性が存在する場合においても, 第 2 章にて $a b$ のもつ物理的意味を考察した通り, 脈波の変化は, 不 均一部での血管壁の形態変化の影響も含んだ応力ーひ ずみ曲線のひずみが零での傾きの大きさに顕著に依存 するということがわかる.

4.3 血管壁性状の異変がもたらす脈波の変化 前 節においては, 不均一部を通過する脈波の変化は，パ ラメータの積 $a b$ によってもたらされることが明らか になった．では，実際には血管壁の形態や力学的性質 の不均一性といった血管壁性状の異変によって, どの ような変化が脈波にもたらされるのであろうか?

まず，血管壁性状を特徵づけるパラメータである $a$ と $b$ は, 式(11) と (12)によると, 不均一部左端 $(n=0)$ から不均一部中点 $(n=L / 2)$ までにおいて, 正常部に 対して分布が減少する場合には, $0<a<1$, および, $0<b<1$ の值をとることになり, 逆に, 正常部に対し

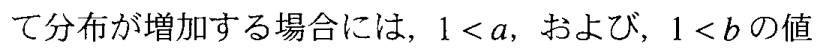
をとることになる.したがって, $a$ と $b$ が取り得る值 の範囲は, 正常部に対する分布の増減によって異なる ことがわかる，つぎに，前節での結果によると，脈波 に変化をもたらす因子は, パラメータの積 $a b$ であり,

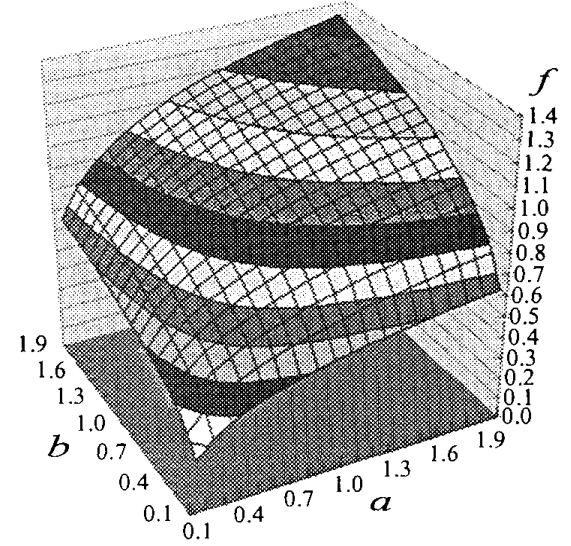

Fig. 5 Maximum amplitude of the pressure wave at $n=50$, which propagetes through the inhomogeneous part: $0 \leq n \leq L / 2$.

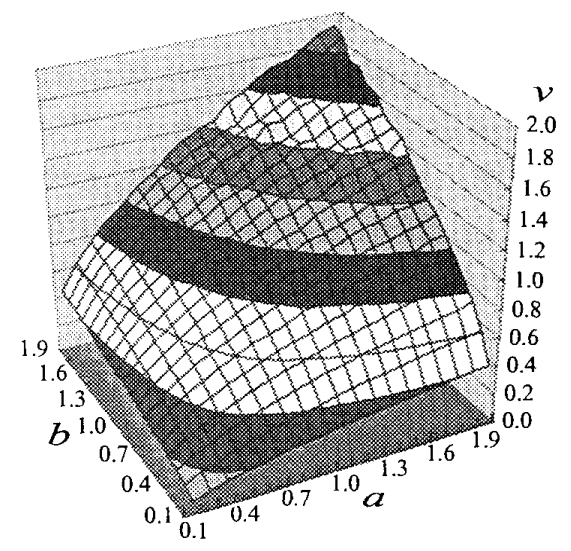

Fig. 6 Velocity of the pressure wave at $n=50$, which propagetes through the inhomogeneous part: $0 \leq n \leq L / 2$.

$a b$ が 1 を超える場合と超えない場合によって脈波の 変化に大きな違いが見られることが明らかになった。

したがって，以上のことから，血管壁性状の異変に よってもたらされる脈波の変化は，血管壁性状を特徵 づけるパラメータ $a$ と $b$ によって，以下の七つの場合 に分類できることがわかる.

I. $0<a<1,0<b<1$, および, $b<1 / a$ の場合.

II. $1<a, 1<b$, および, $b>1 / a$ の場合.

III. $1<a, 0<b<1$, および, $b<1 / a$ の場合.

IV. $1<a, 0<b<1$, および, $b>1 / a$ の場合.

V. $0<a<1,1<b$, および, $b<1 / a$ の場合.

VI. $0<a<1,1<b$, および, $b>1 / a$ の場合.

VII. $b=1 / a$ の場合.

各場合におけるパラメー夕領域を示した相図を図 7 に, また，各場合における， $a$ と $b$ の增減に対する脈波の 振幅と速度の増減，および，反射波の振幅の符号との 関係を表1に示した。ただし，表1において，VIIの 
場合については, $a$ と $b$ の分布の増減は, $b=1 / a$ のも とで一意には定まらず，脈波の振幅と速度には変化が 無く，反射波は発生しないことを意味する，一方，第 2 章によると, 本研究のモデルでは，血管壁の不均一 性は $a$ とbによって記述されることが明らかになった. したがって，図７と表1によると，血管壁の形態や力 学的性質など血管壁の力学的性状に不均一性として生 じた異変と, 脈波の振幅と速度，および，反射波にも たらされる変化との対応関係が，数理的に明確になっ たと理解することができる.

これまでの結果をまとめると, 以下のことが明らか になった. まず，血管壁の形態や力学的性質の不均一 性といった血管壁性状の異変は，本研究のモデルによ ると, パラメータ $a$ と $b$ の値の変化として記述される. つぎに， $a$ と $b$ の值に変化が生じることにより，脈波 には，振幅と速度に変化が生じ，反射波が発生する. さらに，このような脈波の変化を特徵づける因子は， パラメータの積 $a b$ であり, $a b$ の大きさによって, 脈 波の振幅と速度, および, 反射波の振幅が変化する大 きさが決定する. 最後に, $a$ と $b$ の值の変化と, 脈波 の振幅と速度, および, 反射波の振幅の変化との対応 関係が数理的に明らかになった.

本研究では, 脈波の挙動に影響を及ぼす数多くの因 子の中で, 血管壁の形態や力学的性質に焦点を絞り, 坂西モデルという非常にシンプルなモデルを力学的に 一般化して捉えることにより, 病変部だけでなく, 血 管のテーパなども含めて血管壁の力学的性状の変化を 広く考察の対象として取り扱った．その結果，脈波に 影響を及ぼす因子をしぼり，可能な限りシンプルなモ デルを採用したことにより，血管壁性状の変化と脈波 に生じる変化との関係が要因も含めて分類され, 数理 的に明確になった. 本研究の結果は, 今後, 研究を, 脈波に生じた変化を観測することによって血管壁の性 状を検知しようとする技術の開発や，血管壁の病変の 重症度を定量的に評価しようとする技術の確立に展開 していくにあたり，有益な基礎的知見を与えることが できるものと考えられる.

\section{5. 結言}

本研究では, 動脈硬化部や動脈瘤部など血管壁性状 の異変と深くかかわりのある病変部が, 圧力脈波にど のような影響を及ぼすのかということを明らかにする ために，数多くの血管病変の因子の中で，とりわけ血 管壁の形態と力学的性質のみに焦点をしぼり，それら の影響を不均一性として力学的に一般化をして検討す るという観点からアプローチを行った．まず，病変部

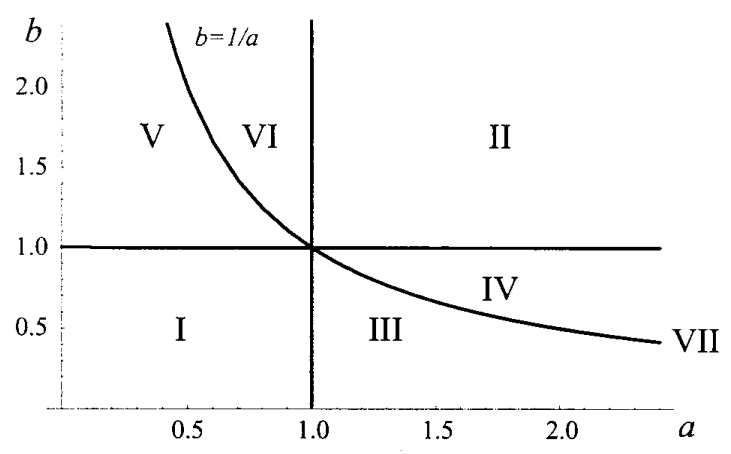

Fig. 7 Phase diagram for the behavior of the pressure wave through the inhomogeneous part.

Table 1 Relation among the parameters. The signs ' $\nearrow$ ' and ' \' mean 'increase / up' and 'decrease / down', respectively. The sign '+' or '-' corresponds with that of the amplitude of the reflected wave $f_{\mathrm{R}}$. ' $\mathrm{N}$ ' means 'Nothing (to change)'.

\begin{tabular}{c||c|c|c|c|c}
\hline & $a$ & $b$ & $f$ & $v$ & $f_{\mathrm{R}}$ \\
\hline $\mathrm{I}$ & $\searrow$ & $\searrow$ & $\searrow$ & $\searrow$ & - \\
$\mathrm{II}$ & $\nearrow$ & $\nearrow$ & $\nearrow$ & $\nearrow$ & + \\
$\mathrm{III}$ & $\nearrow$ & $\searrow$ & $\searrow$ & $\searrow$ & - \\
$\mathrm{IV}$ & $\nearrow$ & $\searrow$ & $\nearrow$ & $\nearrow$ & + \\
$\mathrm{V}$ & $\searrow$ & $\nearrow$ & $\searrow$ & $\searrow$ & - \\
$\mathrm{VI}$ & $\searrow$ & $\nearrow$ & $\nearrow$ & $\nearrow$ & + \\
$\mathrm{VII}$ & Variable & Variable & $\mathrm{N}$ & $\mathrm{N}$ & $\mathrm{N}$ \\
\hline
\end{tabular}

を有する血管の脈波の振舞いを解析するために, 力学 的観点から血管の不均一部を一般的に取り扱う方法を 明らかにした．さらに，血管壁の形態や力学的性質の 影響について構成則の非線形性までも考慮した不均一 部を有する血管の一次元格子モデルを導入し，モデル の方程式を導出した. つぎに, 導出した一次元格子モ デルの方程式を用いて，不均一部を有する血管の脈波 の振舞い，および，脈波に異変を生じさせる力学的要 因と条件について，数值解析により明らかにした. 以 下に得られた主な結果を示す。

（1）血管壁の肥厚や硬化など，血管壁性状の異変を力 学的観点から一般化することにより, 血管壁の形 態や力学的性質の不均一性として捉え, モデルに より, 不均一性が本質的に二つのパラメータ $\left(a_{n}\right.$ と $\left.b_{n}\right)$ によって記述できることを明らかにした。 さらに各パラメータがもつ物理的意味を明らかに し, 特に, 二つのパラメータの積 $a_{n} b_{n}$ が血管壁の 形態変化の影響も含んだ応力-ひずみ曲線のひず 
みが零での傾きという意味をもつことを示した。

（2）血管壁性状の変化, すなわち, 血管壁の形態や力 学的性質の不均一性は, 不均一部を通過する脈波 の振舞いに変化をもたらす.とくに，脈波の振幅 と速度の変化, および, 不均一部にて発生する反 射波の振幅の大きさは，不均一性を特徴づける二 つのパラメータの積 $\left(a_{n} b_{n}\right)$ の大きさによって特 徵づけられる.さらに, 脈波の振幅と速度につい ては, 数值計算結果から, パラメ一夕の積 $\left(a_{n} b_{n}\right)$ との関係を具体的に算出し, 脈波の振幅や速度と 不均一性との関係を明示した。

（3）脈波が不均一部を通過する際に生じる振幅と速度, および，反射波における変化は，血管壁の形態や 力学的性質の不均一性によって異なり，二つのパ ラメー夕 $\left(a_{n} と b_{n}\right)$ を用いて, 七つの場合に分 類できることを明らかにした。ささらに，各場合が 実現される条件を具体的に示した。

近年, 動脈硬化や動脈瘤など血管壁の形態や力学的 性質の異変と関わりが深い血管系疾患に対して, 非侵 襲的で簡便な診断法の確立が強く求められている. 一 方, 実際の血管系疾患では, 様々な要因が複雑に絡み 合い, それらがあいまって異変として現れることが知 られている.ゆえに異変として観測される現象につい て, ひとつひとつの構成要素に分解し，それぞれにつ いて丁寧に詳細を調べることによって, 現象を引き起 こす要因を特定し, 働きを理解し, 現象発生のメカ二 ズムを明らかにすることは，信頼性のある有効な診断 法や治療法の確立に向けたひとつのアプローチとして 大変有用なものになると考えられる.よって，この様 なアプローチの一環として，脈波に影響を及ぼす要因 の中で血管壁性状の異変のみに焦点を絞って得た本研 究の結果は, 実際の臨床に対しては，まだ直接的な適 用は容易ではない段階にあり, 現実的な応用に向けた 次の段階亡して，例えば，血管内の速度分布の考慮 ${ }^{(2)}$ など，種々の要因のひとつひとつをさらに詳細に吟味 していく必要があると思われる.しかしながら, 本研 究の様に, 可能な限りシンプルなモデルを採用して要 因を絞り, 絞った要因についてはりリトンなどを応用 して出来る限り厳密に取り扱うことによって着実に知 見を深めていくことは，血管系疾患に対する診断法の 確立などにむけて非常に重要になると考えられる．実 際に, 本研究の結果からは, 診断において圧力脈波の 振幅や速度に増減が検知された場合には，血管壁の性 状は, 力学的観点からは不均一性を表すパラメー夕に よって分類されたいずれかの状態にあるということが 数理的に明らかになり，血管壁の状態を検知結果から
推定する技術への応用展開に慗がることも考えられる. よって, 本研究の結果は, 今後の信頼性のある診断法 の確立に向けて有用な基礎的知見を与えることができ るものと考えられる.

本研究の一部は, 文部科学省科学研究費の援助を受 けてなされた。ここに感謝の意を表す.

\section{文献}

(1) For example; Liu, H., Yamaguchi, T. and Himeno, R., Blood Flow Simulation in Cardiovascular System, Medical Imaging Technology, Vol.20, (2002), pp.615621 , and references therein.

(2) For example; Bessems, D., Giannopapa, C. G., Rutten, M. C. M. and van de Vosse, F. N., Experimental validation of a time-domain-based wave propagation model of blood flow in viscoelastic vessels, Journal of Biomechanics, Vol.41, (2008), pp.284-291, and references therein.

(3) Hisland, M. B. and Anliker, M., Influence of Flow and Pressure on Wave Propagation in the Canine Aorta, Circulation Research, Vol.32, (1973), pp.524-529.

(4) Kitawaki, T., Shimizu, M., Himeno, R. and Liu, H., OneDimensional Numerical Simulation of Visco-Elastic Tube Transactions of the Japan Society of Mechanical Engineers. A, Vol.69, (2003), pp.55-61.

(5) Watanabe, T., Numerical Analysis for a One-dimensional Lattice Model associated with Material Nonlinearity of Arterial Vessel Wall, Transactions of the Japan Society of Mechanical Engineers. B, Vol.74, (2008), pp.523-529.

(6) Watanabe, T., Effect of Mechanical Properties of a Heterogeneous Part in Blood Vessel on Pulse Wave, Transactions of the Japan Society of Mechanical Engineers. B, Vol.74, (2008), pp.1564-1571.

(7) Watanabe, T., Scale Properties of a One-dimensional Lattice Model for Blood Vessel with a Heterogeneous Part, Transactions of the Japan Society of Mechanical Engineers. B, Vol.74, (2008), pp.1970-1976.

(8) Sakanishi, A., Hasegawa, M. and Ushiyama, Y., Pressure Pulse Wave for Blood Flow in the Aorta from the Viewpoint of the Nonlinear Toda Lattice, Physics Letters A, Vol.221, (1996), pp.395-399.

(9) For example; Blacher, J., Asmar, R., Djane, S., London, G. M. and Safar, M.E., Aortic Pulse Wave Velocity as a Marker of Cardiovascular Risk in Hypertensive Patients, Hypertension, Vol.33, (1999), pp.1111-1117.

(10) Fukui, T., Tsubota, K., Wada, S. and Yamaguchi, T., CFD Study on Pulse Wave Velocity of Stenotic Artery, Proceedings of the 14th JSME Conference on Frontiers in Bioengineering, Vol.2003, (2003), pp.81-82.

(11) Toda, M., Development of the Theory of a Nonlinear Lattice, Supplement of the Progress of Theoretical Physics, Vol.59, (1976), pp.1-35.

(12) For example; Otwinowski, M., Paul, R. and Tuszynski, J., An answer to the question:"Is the arterial pulse a soliton?", Journal of Biological Physics, Vol.14, (1986), pp.43-48, and references therein.

(13) Yoshida, H., Recent Progress In the Theory and Application of Symplectic Integrators, Celestial Mechanics and Dynamical Astronomy, Vol.56, (1993), pp.27-43. 